\title{
Sujeto y conocimiento de sí. Traducción y comentario de dos textos de Pedro de Juan Olivi
}

\section{(1gnacio Anchepe}

\author{
Universidad de Buenos Aires, Argentina
}

Recibido el 18 de febrero de 2019. Aceptado el 18 de marzo de 2019.

\begin{abstract}
Resumen
Estas páginas se proponen presentar la traducción comentada de dos textos de Pedro de Juan Olivi, franciscano provenzal del s. XIII; el primero es el artículo 19 de la Impugnatio quorundam articulorum Arnaldi Gallardi, y el otro es la cuestión 76 de sus Quaestiones in secundum librum Sententiarum. La traducción conjunta de estos textos se justifica por su afinidad temática, pues ambos se refieren a un mismo problema, el que los escolásticos acostumbraron presentar bajo el título "Si el alma se conoce a sí misma por esencia o por especie"; por otra parte, la crítica reciente encontró en ellos indicios de una concepción naciente de sujeto moderno. Luego de presentar someramente cada texto y de algunos datos biográficos imprescindibles de su autor, ofreceré las traducciones. Agregaré solo algunas notas al pie -las necesarias para facilitar la comprensión-y pospondré para el final el análisis de las cuestiones filosóficas, que volcaré en cuatro notas complementarias.
\end{abstract}

PALABRAS CLAVE: ARISTOTELISMO; SIGLO XIII; INDIVIDUO; IMAGINACIÓN.

\section{Subject and Self-Knowledge. Translation and Comment of Two Texts of Peter of John Olivi}

\begin{abstract}
These pages seek to present the commented translation of two texts by Peter of John Olivi, a Provençal Franciscan from 13th century. The first of them is the article 19 of the Impugnatio quorundam articulorum Arnaldi Gallardi, followed by the question 76 of his Quaestiones in secundum librum Sententiarum. The joint translation of these texts is justified by their thematic affinity: both refer to the same problem, which the scholastics used to present under the title "Whether the soul knows itself by essence or by species"; furthermore, recent criticism found in them hints of an incipient conception of modern subject. Translations are placed after a brief presentation of each text and some essential biographical data of its author. Few footnotes were
\end{abstract}


added -only those necessary to facilitate understanding- and the analysis of philosophical issues will be postponed to the end, turned into four complementary notes.

KEYWORDS: ARISTOTELISM; 13TH CENTURY; INDIVIDUAL; IMAGINATION.

Estas páginas se proponen presentar la traducción comentada de dos textos de Pedro de Juan Olivi, franciscano provenzal del s. XIII; el primero es el artículo 19 de la Impugnatio quorundam articulorum Arnaldi Gallardi, y el otro es la cuestión 76 de sus Quaestiones in secundum librum Sententiarum. ${ }^{1}$ La traducción conjunta de estos textos se justifica por su afinidad temática, pues ambos se refieren a un mismo problema, el que los escolásticos acostumbraron presentar bajo el título "Si el alma se conoce a sí misma por esencia o por especie"; por otra parte, la crítica reciente encontró en ellos indicios de una concepción naciente de sujeto moderno. Luego de presentar someramente cada texto y algunos datos biográficos imprescindibles de su autor, ofreceré las traducciones. Agregaré solo algunas notas al pie -las necesarias para facilitar la comprensión-y pospondré para el final el análisis de las cuestiones filosóficas, que volcaré en cuatro notas complementarias.

El Articulus 19 de la Impugnatio fue editado críticamente en 2006; conviene releer las palabras que en esa ocasión escribió su editor, el medievalista francés Sylvain Piron, a fin de calibrar la singular relevancia filosófica de este opúsculo.

En unos pocos años este breve texto accedió súbitamente al rango de texto mayor de la historia de la filosofía occidental. Olivier Boulnois, en Être et représentation, fue quien lo presentó por primera vez como un sorprendente análisis del papel fundador de la certeza subjetiva en un autor de fines del s. XIII. Poco después, Alain de Libera hizo de este mismo texto el lugar de la primera formulación del sujeto moderno (2006a: 1). ${ }^{2}$

En Pentecostés de 1282, el capítulo general franciscano reunido en la ciudad de Estrasburgo había promovido una investigación acerca de unas opiniones sospechosas, presuntamente sostenidas por algunos frailes de Provenza. Entre estos se encontraba Olivi, sobre quien pesaba además una denuncia iniciada por Arnaud Gaillard, uno de sus rivales teológicos. Olivi decidió enfrentar las numerosas acusaciones con un ataque (el sustantivo impugnatio tiene ese sentido) y, durante los últimos meses de 1282, redactó la refutación de una treintena de tesis defendidas por Arnaud y algunas otras sostenidas por personajes de menor envergadura, de lo cual resultó la Impugnatio quorundam articulorum, obra de la cual presentamos el Articulus 19. ${ }^{3}$ Según se lee allí, en una cuestión intitulada An scientia evacuetur in patria, Arnaud había adherido a la posición (aristotélica) de Tomás de Aquino según la cual en esta vida no hay conocimiento (scientia) que no dependa de representaciones imaginativas (phantasmata). En contra de esta posición, Olivi defiende la tesis de que el conocimiento que el alma tiene de sí misma está libre del condicionamiento de las imágenes. ${ }^{4}$

De las numerosas obras de Olivi, el texto filosófico de mayor importancia es aquel conocido como Summa de cuestiones sobre las Sentencias de Pedro Lombardo, texto cuya redacción comenzó luego de sus estudios en París (es decir, luego del año 1272)

\footnotetext{
1 Deseo agradecer a los evaluadores no solo por la elogiosa aprobación de mi trabajo sino también, y sobre todo, por sus correcciones y observaciones, siempre atentas y atinadas; procuré incorporarlas todas, salvo cuando me fue imposible hacerlo.

2 Para las referencias a los trabajos de Olivier Boulnois y Alain de Libera véanse las notas complementarias.

3 La Impugnatio, cuyo título más antiguo es Impugnatio XXXVII articulorum adversus opiniones doctorum quorundam, fue editada una única vez en Petrus Johannis Olivi (1509). Impugnatio XXXV articulorum. En: Ed. Soardi, L. Quodlibeta. Venecia, ff. 42r-49v.

4 Para completar un panorama sobre este texto véanse: Piron, 2010: 451 ss.; Idem, 2006: 258-259; Burr, 1976: 38.
} 
y finalizó a mediados de la última década del s. XIII, pocos años antes de su muerte. De esta obra, que todavía no ha sido íntegramente editada, Bernard Jansen confeccionó la edición crítica de las cuestiones sobre el libro segundo (publicada entre 1922 y 1926) de donde tomo el segundo de los textos, la cuestión 76 (Olivi, Quaest. in II Sent., v. 3: 145-149).

Pedro de Juan Olivi nació alrededor del 1248, al sureste de Francia, en el castillo de Sérignan, región de Occitania. A los 12 años, en 1260, ingresó a la Orden Franciscana. Finalizada su formación, en 1267, fue enviado a París donde tuvo por maestros a los discípulos más célebres de Buenaventura de Bagnoregio: los franciscanos William of Mare, John Peckham y Matteo d'Acquasparta. Debido a una disputa con un fraile de identidad desconocida, nunca obtuvo el título de maestro de teología y debió permanecer como bachiller formado por el resto de sus días. Gracias a este grado académico, ejerció la función de lector en diversos Studia de la Orden, el primero de los cuales fue el estudio general de Montpellier (Occitania). En el marco de los conflictos franciscanos por la interpretación de la regla, Olivi no solo adhirió a la causa de los frailes más estrictos, sino que se convirtió en uno de sus referentes, motivo por el cual entre 1282 y 1287 fue objeto de varias censuras impuestas por las autoridades de su propia orden. Ya contaba con casi 40 años cuando en 1287 un nuevo Capítulo General eligió como Ministro de la Orden a Matteo d'Acquasparta -antiguo maestro suyo- quien lo convocó a exponer su opinión sobre la pobreza franciscana. Al parecer, la opinión de Olivi ganó la adhesión de los frailes, por lo cual fue destinado como lector en el Studium de Santa Croce (Florencia). Allí fue maestro de Ubertino de Casale, futuro líder de franciscanos disidentes de Toscana, recordado en la Comedia de Dante, ${ }^{5}$ e incluso en El nombre de la rosa (donde es presentado como uno de los amigos de fray William de Baskerville). Junto a él, Olivi conoció al joven Dante, quien frecuentaba el Studium de la Santa Croce. Momentáneamente rehabilitado, permaneció en Florencia durante dos años, hasta que en 1289 un nuevo Ministro General, Raymond Geoffroi, lo sacó de Florencia y lo destinó nuevamente a Montpellier. En 1292 fue llevado a comparecer nuevamente ante el Capítulo General y, luego de ser absuelto, regresó a Montpellier, donde pasaría sus últimos años en relativa tranquilidad. Murió en 1298, a los cincuenta años de vida y a los treinta y ocho de haber ingresado a la Orden. ${ }^{6}$

\footnotetext{
5 Dante, Paraíso XII.124.

6 Para completar una introducción a la vida y a la filosofía de Olivi véase Martínez Ruiz, 2005: 13-40; Pasnau y Toivanen, 2018.
} 


\title{
Ataque contra algunos artículos de Arnaud Gallard: Artículo 19 [Impugnatio quorundam articulorum Arnaldi Gallardi, articulus 19] ${ }^{7}$
}

\author{
$<$ La opinión de Arnaud>
}

\1 En la cuestión "Si el conocimiento quedará anulado en el cielo", en la respuesta principal y, más abajo, en la respuesta a la sexta objeción, $<$ Arnaud $>$ dice que el modo propio del conocimiento en esta vida es que se efectúe por medio de la representación imaginativa (fantasmate), con sucesión y con tiempo. En efecto, como se dice en De anima III, capítulo 12, es imposible que el alma intelija sin representación imaginativa. Además, <Arnaud> dice que no ocurre igual cuando el alma está unida al cuerpo y cuando está separada; porque cuando está unida, en vista del acto de inteligir, requiere la debida disposición de los órganos de la imaginación y de la estimativa, debido al hecho de que no intelige sin representación imaginativa, tal como se dice en De anima III. ${ }^{8}$

\section{$<$ Argumentos de autoridad contra la opinión de Arnaud>}

$\int 2<$ No obstante>, esta opinión va contra la doctrina de Agustín, que en muchos pasajes $<$ de su obra $>$ sostiene que el alma se intelige tanto a sí misma como a sus potencias y sus actos internos sin la ayuda del sentido ni de la imaginación. Esto se ve claramente en De trinitate X, desde el capítulo 3 hasta el 12 casi en todo momento, y también en De trinitate IX, en el capítulo 3.

\3 Además, esta opinión también va contra lo dicho por Ricardo, en De archa mystica I, capítulo 6,9 cuando trata sobre el cuarto modo de contemplación, que consiste en <la contemplación ejercida> en la razón y según la razón. Este modo de contemplación ocurre cuando -como dice $<$ Ricardo $>$ - dejada a un lado toda intervención de la imaginación, la mente solo se les enfoca <a los místicos $>$ en aquello que la imaginación no <es capaz de> conocer pero que la razón recoge a partir de la razón y comprende a través de la razón. A una especulación de este tipo nos aplicamos siempre que traemos a la consideración todo lo intangible nuestro (invisibilia) ${ }^{10}$ que conocemos mediante experiencia y captamos por la inteligencia. Y más adelante <agrega Ricardo que> en esta contemplación la mente humana se sirve de la pura inteligencia y que, dejada a un lado toda tarea de la imaginación, nuestra inteligencia misma parece que se ocupa, ella misma y por sí misma, de este asunto. Y en el libro III, capítulo $9,{ }^{11}$ al tratar sobre este grado < de contemplación>, agrega que, así como lo corporal solemos verlo con la sensibilidad corpórea de modo tangible (visibiliter), presencial y corporal, de

\footnotetext{
7 Texto en latín disponible en línea: Oliviana 2 (2006): journals.openedition.org/oliviana/56.

$8 \mathrm{Al}$ parecer no se conserva el texto de Arnaud; en todo caso, la quaestio que critica Olivi versaba indudablemente sobre la scientia de los bienaventurados y seguramente indagaba hasta qué punto podía perdurar en ellos un conocimiento adquirido previamente, es decir, en dependencia de una sensibilidad corpórea de la cual la muerte los había despojado; se infiere que, en este contexto, Arnaud hacía un "aristotélico" hincapié en la dependencia del alma respecto de la sensibilidad durante la unión con el cuerpo.

9 De archa mystica es un tratado contemplativo escrito por Ricardo de San Víctor; fue editado bajo el título De gratia contemplationis seu Benjamin Major en Migne, PL 196 (el pasaje citado por Olivi se encuentra en la columna 71). Hay una edición más reciente: Richardus a Sancto Victore (1996). Benjamin Maior. Ed. Aris, M.-A. Contemplatio: Philosophische Studium zum Traktat Benjamin Maior des Richard von St. Victor. Frankfurt am Main: Josef Knecht (Fuldaer Studien 6).

10 Traduzco invisibilia nostra por "todo lo intangible nuestro", es decir, nuestro mundo interior (dimensiones no corpóreas de nuestro ser) al que accedemos mediante la intuición racional cuya existencia Olivi se propone reivindicar en este texto. Según un hábito de traducción predominante, alguien podría esperar "nuestras cosas invisibles", expresión que descarto explícitamente por demasiado oscura.

11 Ricardo de S. Víctor, Ben. Maior III.9.
} 
la misma manera, esta sensibilidad intelectual (intellectualis ille sensus) capta lo intangible intangiblemente (invisibilia invisibiliter), aunque sin duda de modo presencial y esencial. ${ }^{12}$

\section{$<$ Respuesta de Olivi:nueve argumentos>}

\$4 Y esto mismo [sc. la falsedad de la opinión de Arnaud] lo demuestra, en primer lugar, lo actual, lo proporcionado y lo presente de muchos objetos intelectuales. En efecto, está claro que las potencias de nuestra mente, como así también sus actos y sus hábitos, no son ni menos actuales, ni menos inteligibles, ni están menos presentes, ni son menos proporcionados a nuestro intelecto que las representaciones de la imaginación. ${ }^{13}$

S5 En segundo lugar, lo demuestra el poder de <la mente> de volverse sobre sí misma (reflexionis), sin lo cual un hombre pierde el uso del libre albedrío. En efecto, si nuestra mente solo puede inteligir algo a condición de que intermedien unas representaciones imaginarias hacia las cuales volverse a fin de examinarlas, entonces <nuestra mente> nunca puede volverse y dirigirse inmediatamente sobre sí misma. Pero si <la mente> es capaz de hacer esto, entonces se contemplará inmediatamente a sí misma, a título de su <propio> objeto íntimo e inmediato. ${ }^{14}$

\$6 En tercerlugar, lo muestra lo diverso de las representaciones imaginativas -y de lo sensible <en general $>-<$ con respecto $>$ de lo intelectual de nuestra mente. En efecto, está claro que tanto las representaciones imaginativas como las cosas sensibles no pueden representar lo intelectual de nuestra mente de modo unívoco, propio y específico, sino mediante una analogía muy alejada, y mediante negación más que por vía positiva. Pero carece de sensibilidad interna quien ${ }^{15}$ no vea que $<$ de hecho $>$ somos capaces de captar <los contenidos $>$ intelectuales de nuestra mente, $<$ incluso $>$ en lo que difieren respecto de las representaciones imaginativas y de lo sensible $<$ en general $>$, y esto no solo por vía negativa sino también positivamente. Por eso conocemos perfectamente, e <incluso > experimentamos, qué es inteligir, qué es querer, qué es creer, y <además> conocemos y sentimos perfectamente las diferencias específicas de <las distintas clases de > actos de querer. En efecto, conocemos y sentimos que una cosa es saber geometría, y otra astronomía, y otra metafísica, etc., o bien, que una cosa es esta conclusión y otra aquella otra conclusión; y de manera semejante, sabemos que una cosa es el afecto de soberbia y su consentimiento, y otra el de humildad, etc. ${ }^{16}$

S7 En cuarto lugar, lo demuestra el poder < de nuestra mente> de entender las nociones generales de las virtudes y los vicios, y de lo malo y de lo bueno, todo lo cual ni

12 Es notorio que haya sido en la literatura mística donde Olivi encontró auctoritates a favor de la posibilidad de un ejercicio intelectual emancipado de la dependencia de la sensibilidad.

13 La concisión del argumento perjudica su claridad. Las representaciones imaginativas son superfluas porque las potencias, los actos y los hábitos de la mente están por sí mismos tan presentes ante la mente que cualquier ítem intermedio se torna superfluo. La presencia anula la necesidad de la representación y, por lo mismo, el único motivo para recurrir a ella es la ausencia. Olivi utiliza este mismo argumento contra las especies inteligibles (Quaest.in II Sent., v. 2: 468), décadas más tarde lo retomará Guillermo de Ockham en Reportatio, l. II, q. 13.

14 Se trata de una reductio ad absurdum presentada disyuntivamente. Si el hombre solo pudiese ejercer la intelección mediante representaciones imaginarias, sería incapaz de volverse sobre sí mismo y carecería de libre albedrío; sin embargo, está claro que esto último no es así. Sobre la relación entre representación imaginativa y libre albedrío véase la tercera nota complementaria.

15 Los manuscritos ofrecen dos lecciones posibles, que y quod; Sylvain Piron en su edición crítica elige la segunda. Por mi parte, solo logré encontrarle sentido a la oración ope ingenii, leyendo qui.

16 El argumento combina el recurso a la experiencia con la premisa de que una imagen-de orden sensible-es incapaz de representar adecuadamente una realidad de orden intelectual. 
es sensible, ni podemos recolectarlo de lo sensible por lo menos de modo universal, ni podemos representarlo mediante representaciones imaginativas, ni abstraerlo de estas. ${ }^{17}$

\$8 En quinto lugar, lo demuestra el alcance de la potencia intelectual y la trascendencia de su objeto. En efecto, está claro para toda mente católica que el intelecto no está ${ }^{18}$ limitado por esencia a lo sensible e imaginable; de no ser así, nunca podría ser llevado a la contemplación de las sustancias separadas sin una transformación de su <propia > especie. Además, también está claro que el objeto del intelecto trasciende lo corpóreo y lo sensible. De otra manera, no podríamos captar la noción de ente, por cuanto esta es más alta y más general que aquellos [sc. lo corpóreo y lo sensible]. Por tanto, no es posible inferir ni de la naturaleza del intelecto ni de la naturaleza de su objeto el que no se pueda inteligir sin representación imaginativa; más bien debe inferirse lo contrario. ${ }^{19}$

\$9 En sexto lugar, lo demuestra la eminencia de las revelaciones divinas y angélicas. En efecto, ¿quién se atreverá a decir que, en el estado de viador, Dios o los ángeles solo pueden revelar algo a nuestra mente mediante representaciones imaginativas? De aquí que el hermano Guillermo de la Mare, en su Correctorium, ${ }^{20}$ corrigiera a propósito de este tema a Tomás, a quien Arnaud parece seguir en este punto. ¿Quién dirá que los varones contemplativos, en sus gustos y excesos supramundanos, saborean lo divino mediante representaciones imaginativas y no de otro modo? Según Dionisio, en el libro De mystica theologia, en vista de actos como estos se requiere el abandono natural de los sentidos y de las cosas sensibles, e inclusive, de alguna manera, de las operaciones intelectuales. ${ }^{21}$

\10 En séptimo lugar, lo demuestra la infalible certeza del propio existir (esse). En efecto, el hombre sabe tan infaliblemente que existe y que vive que no puede dudar de esto. Y si el hombre supiese que existe y que vive solo mediante las representaciones imaginativas, surgiría, no sin motivo, una duda sobre esto, pues estas representaciones no podrían representar directa y conformemente el hecho de que vive y existe, sino muy indirecta y deformadamente; y no podrían representarlo per se y primeramente sino solo a través de múltiples comparaciones y razonamientos. Por eso, los autores de esta posición [sc. que Olivi está criticando] dicen que llegamos a conocer nuestra mente y nuestra potencia intelectiva mediante los actos de esta, y al conocimiento de los actos mediante el conocimiento de los objetos. ${ }^{22}$ En efecto, razonando inferimos que esos actos con que conocemos los objetos emanan de una cierta potencia y sustancia y que existen en algún sujeto. Y así, de este modo, nos damos cuenta de que tenemos una cierta potencia de la cual estos actos emanan. Pero si alguien inspecciona mejor esta solución, encontrará que puede surgir una cierta duda en esta inferencia y que, además, nunca llegamos por este camino a la certeza de que existimos, vivimos e inteligimos. En efecto, aunque estemos ciertos de que esos actos emanan de una potencia y de que existen en algún sujeto, ¿cómo llegaremos a saber a través de esta inferencia que nosotros somos ese sujeto y que esa potencia es la nuestra? ${ }^{23}$

17 Nuevo argumento a partir de la irrepresentabilidad de lo mental: las nociones de virtud, vicio, bien y mal.

18 Me aparto de la edición de Piron y sigo el manuscrito B, que omite el infinitivo esse.

19 La conclusión de Olivi es diametralmente opuesta a la de Aristóteles. Llega a ella enfatizando lo inconmensurable de lo intelectual respecto de lo sensible. Mientras que la abstracción aristotélica tiende a exaltar la continuidad de ambas esferas y a ver en ellas una diferencia de grado, Olivi presupone una diferencia cualitativa. Si para concluir la no dependencia respecto de las imágenes alcanza con que el intelecto humano sea capaz de contemplar las sustancias separadas y de captar la noción de ente, se debe a que Olivi presupone una muy marcada diferencia de orden entre ambas esferas.

20 Olivi se refiere al Correctorium Fratris Thomae editado por Glorieux, P. (1927) en Les premières polémiques thomistes I: Le correctorium corruptorii "Quare". Kain: Le Saulchoir.

21 Ps. Areopagita, De mystica theologia IV y V.

22 Sobre este punto véase la primera nota complementaria.

23 Las secciones $\iint 10-11$ son las más importantes por su extensión pero, sobre todo, por su densidad conceptual. Si la 
\11 En octavo lugar, esto lo demuestra la certeza que tenemos sobre el individuo que subyace a (supposito) ${ }^{24}$ todo acto cognoscitivo. En efecto, alguien tiene certeza cognoscitiva de algo solo si sabe que lo sabe, es decir, solo si sabe que es él mismo el que lo sabe. ${ }^{25} \mathrm{Y}$ esta certeza sobre el individuo que subyace $<\mathrm{al}$ acto $>$ se da universalmente siempre que captamos nuestros propios actos. En efecto, solo capto mis actos (por ejemplo, actos de ver, de hablar, etc.) cuando capto que yo veo, oigo, reflexiono, etc. Y en esta captación, la captación del individuo mismo parece preceder por orden natural $<$ a la captación del acto>. ${ }^{26}$ De aquí que, cuando queremos anunciarles esto a otros, anteponemos la persona diciendo: "yo pienso esto" o "yo veo esto", etc. Sin duda, según un orden natural, se capta el sujeto antes que el predicado que se le atribuye en cuanto tal, y nosotros solo captamos nuestros actos como predicados de nosotros o atribuidos a nosotros. Inclusive, cuando captamos nuestros actos, distinguimos, gracias a un cierto sentido interno y como experimentalmente, entre la sustancia -de la cual estos actos emanan y en la cual existen- y los actos mismos. Por eso, percibimos sensiblemente que estos emanan del alma y dependen de ella, y no ella de aquellos, y percibimos que ella misma es algo fijo que permanece en sí, mientras que los actos mismos están en un cierto continuo devenir. Pero no podrían estar en estas <condiciones> si el individuo <que subyace a $>$ nuestros actos solo pudiéramos conocerlo a través de representaciones imaginativas interpuestas y de razonamientos intermedios realizados a partir de la captación de nuestros actos. ${ }^{27}$

\12 En noveno lugar, esto lo demuestra el poder del alma separada. En efecto, está claro que, en el estado de inocencia, el cuerpo no le pesaba al alma, o por lo menos no le pesaba con un peso enorme y violento; y también está claro que por la separación misma del alma respecto del cuerpo la sustancia del intelecto no crece. Pero si la unión con el cuerpo le impidiese completamente al alma el conocimiento inmediato de sí misma y de lo intelectual <que hay en ella>, entonces, después de separarse del cuerpo, o bien (i) continuaría teniendo este impedimento, o bien (ii) sucedería una de las <alternativas> predichas: o (ii.a) que a causa del cuerpo estaría cargada con una enorme violencia, o (ii.b) que por separarse del cuerpo crecería la sustancia del intelecto o alguna potencia de este; pero no corresponde admitir nada de esto. De aquí también puede quedar claro que nuestro intelecto no está obligado <a recurrir $>$ a las representaciones imaginativas debido a la naturaleza de su unión <con el cuerpo >. Y ya que el pecado original no nos consumió a nivel sustancial (aunque nos haya limitado mucho a nivel natural), no es forzoso que seamos absolutamente incapaces de inteligir sin representaciones imaginativas. No obstante, a causa de la limitación <impuesta por> nuestra corrupción, nuestro intelecto está muy contaminado de representaciones imaginativas, y muy oscurecido y debilitado en sus $<$ facultades $>$ intelectuales. ${ }^{28}$

intelección -argumenta Olivi- estuviese mediada por representaciones imaginativas sería forzosamente inferencial o procesual, y, en ese caso, el conocimiento de sí (en cuanto intelección mediada por imágenes) sería incapaz de proporcionar una certeza infalible de la propia existencia. Merece especial atención la pregunta con que termina §10: Olivi supone que no hay ningún razonamiento ni inferencia que pueda empezar en tercera persona y concluir en primera, los razonamientos pueden mostrar características esenciales del alma, pero son incapaces de proporcionar la certeza vivida del yo, hay una irreductible inconmensurabilidad entre ambos tipos de conocimiento.

24 Amparado por la autoridad de Boecio -que definió suppositum como substancia individual de naturaleza racional-traduzco este término por la perífrasis "individuo que subyace a", y descarto "supuesto", calco tan divulgado como oscuro.

25 Los estudiosos advirtieron la notable semejanza de esta idea oliviana con la "KK-Thesis" sostenida por Jaakko Hintikka. Al respecto, véase la cuarta nota complementaria.

26 Nótese que la conclusión oliviana invierte la tesis aristotélica expuesta en el párrafo anterior según la cual el proceso inferencial va del acto a la potencia y de esta al alma.

27 Los argumentos de $₫ 10$ y $\ 11$ están estrechamente conectados, pero son distintos. En $\ 10$ se argumenta la inviabilidad de que certeza infalible de la existencia propia pueda inferirse a partir de un razonamiento que parta de representaciones imaginativas. En $\int 11$ se profundiza en esta certeza infalible y se analiza su contenido. Al percibirse a sí misma, el alma, además de captar su propia existencia, se descubre sujeto y principio de sus propios actos, lo cual resulta confirmado por el hecho de que el sujeto precede naturalmente al predicado, es decir, por una estructura atributiva a la vez ontológica y gramatical. Alain de Libera relacionó esta tesis con la "superstición" de lógicos y gramáticos deplorada por Nietzsche en el parágrafo 17 de Más allá del bien y del mal; véase la cuarta nota complementaria. 


\section{$<$ Respuestas a posibles objeciones $>$}

\13 Se me puede objetar aquel pasaje de Dionisio en el primer libro de la Jerarquía Celestial según el cual el rayo divino solo puede iluminarnos a través de una multiplicidad de velos sagrados, anagógicamente y cubierto por ellos, y que lo inmaterial y simple solo podemos contemplarlo mediante lo figurable y sensible. ${ }^{29}$ Debe responderse que Dionisio, con el término "figurables" y "sensibles" no pretende aludir a lo que es familiar a nuestra captación, <lo cual le resulta > propio, connatural y proporcionado <a ella $>$. Esto queda claro por sus propias palabras, allí mismo cuando afirma esto que acabo de citar. De aquí que, frecuentemente, llame a nuestro intelecto "pasible" y "material", con respecto al intelecto del ángel y de Dios: no se expresa en estos términos porque nuestro intelecto sea a secas de este modo sino porque en nosotros abunda más el conocimiento de cosas sensibles que el conocimiento de las intelectuales, y porque estamos tan inviscerados ${ }^{30}$ de cosas sensibles que casi toda nuestra inteligencia parece estar mezclada y empapada de ellas. Además, en ese mismo pasaje, entre otras imágenes de cosas supracelestes, Dionisio afirma que el conocimiento de las Sagradas Escrituras es una imagen de la contemplación superintelectual y superplena de los ángeles. ${ }^{31}$ Pero si Dionisio no entendiese las cosas así, ${ }^{32}$ en vano habría distinguido la teología sobre los nombres divinos de la teología simbólica por ascender a lo divino la primera mediante lo intelectual y la segunda por lo sensible. Según esto, ${ }^{33}$ en efecto, toda nuestra teología sería simbólica y no habría teología intelectual (en cuanto la teología intelectual se diferencia de la simbólica según Dionisio). ${ }^{34}$

\14 También puede objetárseme aquel pasaje de Ricardo -en Sobre el arca mística, libro III, capítulo 9- según el cual el alma no es capaz de verse a sí misma, es decir, de ver la esencia del alma misma; o bien otro pasaje -de ese mismo libro y capítulo- que dice lo siguiente: “¿Quién, pregunto, que exista todavía en esta carne vio o pudo ver su propia alma o cualquier otra sustancia espiritual en su pureza?; sin duda, aquí la mente humana es ciega de nacimiento". 35 Debe responderse que Ricardo pretende sostener que el alma no ve todos los aspectos de su esencia, tales como su simplicidad o muchas otras de sus condiciones especiales. Por eso, en el capítulo 9, antes de las palabras citadas, dice lo siguiente: "no obstante, el alma ve con este ojo todo lo que está de este lado del velo, es decir, sus <aspectos> invisibles, que son todo aquello que está dentro de sí misma; pero no ve todo porque no todo está de este lado del velo y con su ojo, con el cual solo ve algunas cosas suyas, no es capaz de verse a sí misma,

dos típicos del imaginario cristiano: el anterior al pecado original y el posterior a la muerte (entendida como una separación de alma y cuerpo). En este contexto, que el intelecto dependa de las imágenes equivale a decir que el cuerpo es un peso perjudicial para el alma (Olivi parte de esta presuposición, la da por sentada). Ahora bien, si luego de separarse del cuerpo, el alma ni incrementa su agudeza intelectual ni continúa padeciendo el presunto impedimento de las imágenes, se infiere que no dependía de las imágenes durante su unión con el cuerpo. En definitiva, este argumento exhibe trazas de la "ideología anticorporal" vigente en el Medioevo latino a partir del s. XIII; véase Le Goff y Truong, 2005: 45.

29 Ps. Areopagita, De colesti hierarchia 1, \$2.

30 El discurso filosófico oliviano abunda en metáforas (lo cual no deja de ser paradójico si se tiene en cuenta el agudo rechazo por las imágenes que profesó el franciscano y su generalizada sospecha de la sensibilidad). El verbo inviscerare y sus derivados nominales aparecen con frecuencia en sus textos (casi una veintena de ocurrencias en las Quaestiones in secundum Sententiarum); estos términos expresan con contundente plasticidad la íntima unión del alma con su objeto, ya sea que se trate de una unión deseable (cuando el aspectus intelectual se une con la cosa individual sin la mediación de especies), ya sea que se trate de una unión perjudicial (tal el caso de la afición producida por un deseo malo o la excesiva compenetración con lo sensible). Opto por calcar el término -y por el consiguiente neologismo en español-a fin de transmitir esta riqueza de significados.

31 Ps. Areopagita, De cœlesti hierarchia 1, \$3.

32 Es decir, si no aceptase la legítima existencia de un rango de realidades proporcionadas y connaturales a nosotros, cuya captación puede prescindir del recubrimiento de lo sensible.

33 Es decir, según el modo como la objeción interpreta la cita dionisiana.

34 La profusión de auctoritates no debe confundirnos. Poniendo en práctica un estilo hermenéutico típico de su época, Olivi reinterpreta las fuentes tradicionales a fin de justificar con ellas sus propias ideas novedosas.

35 Ricardo de S. Víctor, Ben. Maior III.9. 
es decir, la esencia misma del alma". ${ }^{36}$ He aquí que Ricardo sostiene que el alma es capaz de ver ciertos aspectos suyos. Y lo mismo sostiene en el noveno capítulo, antes de las palabras citadas arriba, mediante una indagación argumentativa.

\15 Tal vez se me pregunte cómo es posible que el alma sea capaz de captarse inmediatamente a sí misma pero, sin embargo, no discierne claramente que es simple y completamente distinta de las cosas corporales, y que solo puede notarlo por medio de una indagación argumentativa (motivo por el cual <estas características del alma> solo llegan a conocerlas los sabios). Debe responderse que esto mismo podría preguntarse sobre los actos del alma y sobre sus representaciones imaginativas, sobre las cuales <nuestros rivales> suponen que el alma las observa inmediatamente. En efecto, <según la posición de ellos>, el alma no es capaz de discernir ni su propia simplicidad ni muchas otras propiedades de esos <actos y esas representaciones que observa inmediatamente>; de hecho, a veces cree que las representaciones imaginativas son cosas exteriores.

\section{$<$ Aclaración finals}

\16 Finalmente, también debe tenerse en cuenta lo siguiente. Las cosas las captamos de una manera por medio del sentido del tacto y del gusto, y de otra manera por medio de la visión, aunque los tres sentidos capten inmediatamente sus objetos. E inclusive, mediante la visión, captamos las cosas de una manera si el ojo está legañoso o el medio $<$ a través del cual estamos viendo > está lleno de humo y es espeso, pero las captamos de otra si el medio <a través del cual estamos viendo> es transparente. De la misma manera, el intelecto de los ángeles o el de los bienaventurados se capta a sí mismo de una manera, mientras que el nuestro lo hace de otra. En efecto, el nuestro se capta a sí mismo y a la sustancia de nuestra mente a la manera del tacto o a la manera de una visión muy legañosa y oscura. Así como el tacto siente que su objeto está presente ante él pero no es capaz de discernir las características visibles de este, del mismo modo nosotros sabemos con toda certeza y de una manera íntima que existimos, aunque no podamos discernir nuestras propiedades intelectuales con claridad y nítidamente (visibiliter). Y si logramos conocer alguna de ellas superficial (in generali), indeterminada y oscuramente, la conocemos al modo como ve una vista legañosa. ${ }^{37}$

\17 Por este motivo ocurre que algunos a veces creyeron erróneamente que la mente es fuego o algún <tipo de> cuerpo, como atestigua Agustín de De trinitate II. No es que no tuviesen certeza de que esta es un ser (res) viviente e inteligente; sin embargo, como dudaban si este ser es simple e incorpóreo -y a causa de una captación inmoderada ${ }^{38}$ y demasiado inoportuna de lo sensible y representable por la imaginación- terminaron creyendo que la mente más bien era extensa y corporal, más que incorpórea.

\18 Y con esto también queda refutada la objeción de por qué <una mente en estado de unión $>$ no puede ver las almas separadas aunque estas últimas sean tan proporcionales a su intelecto como lo es ella misma. Por un lado, esto es porque las otras almas no están introducidas < dentro de la mente > ni <están > íntimamente presentes en su interior, que es donde su intelecto está como oculto. Y por el otro, porque su intelecto, a fin de captar claramente lo intelectual, no difunde su aspectus fuera de sí, sino que lo tiene recogido dentro de sí al modo del tacto, y lo tiene limitado dentro

36 Ricardo de S. Víctor, Ben. Maior III.9.

37 Susan Brower-Toland subraya la frecuencia con que Olivi utiliza metáforas sensoriales para caracterizar la conciencia autorreflexiva; añade que la propensión a esta metáfora es comprensible sobre todo teniendo en cuenta que, según Olivi, el sentido del tacto es en sí mismo un modo autoreflexivo de conciencia (2013: 141 Ss.).

38 En la edición de Piron se lee nimia y no se consigna ninguna lección alternativa; sin embargo, la edición veneciana trae nimiam, que es la lección que sigo. 
de sí al modo de la vista miope. ${ }^{39}$ Con todo, algún ángel podría introducírsenos de manera que sintiésemos -como por un cierto gusto y tacto confuso- algo inefable y supramundano presente dentro de nosotros, tal como lo sentían las mentes dotadas de profecía. <Aquí> me refiero a este tema con algún detenimiento porque en alguna ocasión vi que Arnaldo se opone con vehemencia a esta verdad; de todas maneras, para una explicación más completa habría que decir bastante más.

\19 Como, en este tema, Arnaldo junto con Tomás de Aquino se basan en Aristóteles, concedo que este último se equivocó en este punto, tanto en De anima III, como en Física I y al final de Analíticos Posteriores I y II, aunque generalmente bien podría decirse que habla sobre objetos sensibles en la mayoría de los pasajes. ${ }^{40}$ En efecto, puede ser cierto que nuestro intelecto es incapaz de inteligir las cosas sensibles sin la intervención de un acto de la imaginación o del sentido común, pero lo es a condición de que entendamos correctamente el término "mediación", y no como lo entiende Averroes, que parece sostener que el intelecto no capta las particularidades de los seres sensibles per se sino solo peraccidens. ${ }^{41}$

39 Opto por no traducir aspectus, tecnicismo fundamental de la filosofía oliviana. Hacia fines del s. XIII, se discutía sobre el alma y su actividad desde la perspectiva de la physica aristotélica, es decir, en términos de causa, efecto, actividad y pasividad. Según Olivi, todas las potencias del alma desempeñan una función completamente activa, no solo la voluntad o los apetitos sino también el intelecto y los sentidos. El franciscano refuta extensamente las tesis que explican el conocimiento como una recepción pasiva de determinaciones provenientes del objeto y reivindica la idea de que conocer consiste en un activo enfoque de la atención sobre la cosa; a esta atención la denomina aspectus (en el texto traducido se enfatiza su carácter interior comparándolo con el tacto). A propósito de este término se ha advertido acertadamente que es "difícil de traducir debido al amplio uso que Olivi hace de él; Pasnau lo traduce como 'atención' lo cual es válido en el caso del aspectus del sentido común y del intelecto, pero no resulta así cuando Olivi se refiere al aspectus del sol o de una flecha; otra posible traducción podría ser el derivado directo de la palabra latina, a saber, 'aspecto'; [...] otra traducción podría ser 'orientación'; con todo, ambas traducciones resultan toscas y poco orientativas; finalmente, podríamos usar 'inclinación', pero esta traducción suscitaría confusión con el aspecto voluntario, central para Olivi; por tanto, en orden a reducir malentendidos, conviene que el término quede sin traducir en la mayoría de las ocasiones" ( Toivanen, 2013: 157). Puede verse Quaest. in II Sent., v. 3: 63-4, donde Olivi define el aspectus (visual) comparándolo con la punta de una espada; al respecto véase Anchepe, 2018: 21 .

40 Se advierte el prejuicio de que Aristóteles, filósofo pagano, es incapaz de llevar su indagación más allá de lo corpóreo. Al respecto, Olivi escribió una carta, De perlegendis philosophorum libris ("Acerca de la lectura de los libros de los filósofos"), donde expone sus prejuicios para con la filosofía griega; hay traducción española en Martínez Ruiz, 2005: 227-240. Acerca del valor que, según Olivi, deben tener Platón, Aristóteles y la filosofía en general para un cristiano véase Burr, 1971: 56-7.

41 Averroes quizás represente el máximo rival de Olivi en el tema que tratan estos textos. Más radical que los aristotélicos latinos, sostuvo que toda individualidad -no solo la del objeto sino también la del sujeto- es impedimento de la intelección; por eso concluyó, en cuanto a lo objetivo, que lo individual concierne a la sensibilidad y, en cuanto a lo subjetivo, que el intelecto humano debe estar separado de toda singularidad y, por ende, ser único; al respecto véase Puig Montada, 2005. 


\section{Cuestión 76: ¿De qué manera el alma se conoce a sí misma?42}

A partir de lo dicho <en las cuestiones precedentes> es fácil ver algo que muchos investigaron trabajosamente y algunos trataron erróneamente, a saber, de qué manera el alma se conoce a sí misma; (i) si lo hace por medio de una especie o bien por medio de su esencia, y (ii) si lo hace por medio de una reflexión inmediata de su aspectus sobre sí misma o bien dirigiendo primeramente su aspectus hacia las representaciones imaginativas, es decir, hacia las especies imaginarias recibidas por los actos de los sentidos exteriores. ${ }^{43}$

\section{$<$ Primera objeción $>$}

Esta segunda opinión [sc. la que alude a las representaciones imaginativas] la sostienen los estudiosos de Aristóteles. Este, como veía que el alma del niño, la del demente y la del que duerme son incapaces de conocerse a sí mismas en acto, creyó 44 que esto era imposible <de por sí y para todos los hombres $>$, pues si el alma fuese de por sí objeto suficiente <de conocimiento para sí misma> podría generar su propia especie en su intelecto. O bien, si el intelecto se bastase de por sí <para conocer el alma a la que pertenece>, la conocería tanto a esta como a sí mismo. Y por eso, creyó que nuestra naturaleza intelectual es a las inteligencias separadas lo mismo que una sombra es a la luz, o bien, lo mismo que el aire -que de suyo es oscuro- es al sol y a las cosas visualmente coloreadas. ${ }^{45}$

En efecto, lo mismo que la transparencia del aire no es por sí sola visible para nosotros pero puede recibir por sí sola la luz y las especies del color, de la misma manera, según estos [sc. los estudiosos de Aristóteles] nuestro intelecto posible no es inteligible de por sí ni siquiera para sí mismo, pero mediante una luz aneja a él-a la que denominan "intelecto agente"- se abstraen las especies inteligibles a partir de las especies imaginarias. Y por medio de esas <especies> así abstraídas, intelige primeramente las cosas sensibles y, después, razonando, <intelige > que ese principio y sujeto es un principio de vida simple, incorpóreo y formal. Y de esta manera el alma llega a anoticiarse de sí misma. ${ }^{46}$

42 El texto en latín se encuentra en Olivi, Quaest. in II Sent., v. 3: 145-149.

43 Olivi combina dos problemas conectados pero distintos, pues se pregunta por el medio a través del cual el alma se conoce a sí misma y si la reflexión a través de la cual se conoce es un acto autónomo o bien dependiente de otro acto previo; véase Putallaz, 1991: 90 (el segundo capítulo de este libro está dedicado íntegramente a la cuestión 76 y al problema del conocimiento de sí en Olivi). Sobre la noción de aspectus véase la nota 39.

44 Bernardus Jansen, en su edición crítica, anota DA III.4, 5, 7 y 8, 429b30 ss.

45 El argumento sobre niños, dementes y durmientes no parece encontrarse en Aristóteles; no obstante, bien puede ser elaboración de Olivi a partir de algunas premisas. En los tres textos aristotélicos referidos al sueño (Acerca del sueño y de la vigilia, Acerca de los ensueños y Acerca de la adivinación por los sueños) (i) los durmientes aparecen asociados a otras figuras de irracionalidad: niños, dementes, animales, enfermos, melancólicos, etc.; esos tratados equiparan (acaso involuntariamente) una serie de estados mentales cuyos rasgos comunes son un debilitamiento del intelecto y el trastorno de las representaciones imaginativas. Por otra parte, (ii) el sueño consiste en un páthos que afecta el sentido común (In Somn. 455a10), potencia gracias a la cual percibimos que vemos u oímos y que proporciona, por tanto, un cierto tipo de conocimiento de sí. Finalmente, (iii) en estos tres textos, las imágenes producidas en dichos estados mentales son fuente de confusión y error. Agreguemos -a propósito de las últimas líneas de la objeción- que en DA III.5, $430 a 15$ se compara el intelecto agente con la luz.

46 Dos pasajes de las Quaestiones disputatae de Veritate de Tomás de Aquino ilustran muy bien lo mediato y procesual del conocimiento de sí según la opinión combatida por Olivi. Tomás, De Verit., q. 10, a. 8, 321b: "En lo concerniente al conocimiento actual con el cual alguien considera en acto que tiene alma, sostengo que el alma se conoce por medio de sus actos, pues alguien < solo> advierte que tiene alma, y que vive, y que existe cuando advierte que él <mismo> siente e intelige, y que ejerce otros actos de la vida por el estilo" [Quantum igitur ad actualem cognitionem, qua aliquis se in actu considerat animam habere, sic dico, quod anima cognosciturperactus suos. In hoc enim aliquis percipit se animam habere, et vivere, et esse, quod percipit se sentire et intelligere, et alia huiusmodi vitae opera exercere]. De Verit., q. 10, a. 8, 322a: "Nuestra mente no puede conocerse a sí misma de modo tal que se capte inmediatamente a sí misma; en cambio, a partir del hecho de que capta otros seres, llega al conocimiento de sí. [...] Esto puede verse claro observando el modo cómo los filósofos investigaron la naturaleza del alma. A partir del hecho de que el alma humana conoce las naturalezas universales de las cosas, advirtieron que la especie por la cual inteligimos es inmaterial [...]. Y a partir del hecho de que la especie inteligible es inmaterial, advirtieron que el intelecto es una cierta realidad que no depende de la materia. Y a partir de esto avanzaron al conocimiento de las otras 


\section{$<$ Segunda objeción $>$}

Además, $<$ los aristotélicos $>$ se convencieron de su opinión ${ }^{47}$ porque veían que muchas personas <razonan > equivocadamente acerca de ese conocimiento <que tienen $>$ de su propia mente. En efecto, algunos < filósofos $>$ creyeron que esta es fuego, y algún otro creyó que era cuerpo; y otros creyeron que era una forma corpórea, extensa y mortal; y otros creyeron que no era la forma de un cuerpo sino solo un motor unido punitivamente a un cuerpo.

A partir de esto se ve que, según las variadas imaginaciones y las argumentaciones deducidas de ellas, se suscitaron en el alma <de esos filósofos > variadas opiniones acerca de su propia naturaleza. Pero esto no habría ocurrido si el alma fuese capaz de observarse a sí misma mediante un volverse inmediato de sí sobre sí, es decir, si fuese capaz de ver su propia esencia o naturaleza. En efecto, <si ese fuese el caso>, vería ostensiblemente que ella es distinta de cualquier cuerpo más de lo que difiere lo blanco de lo negro, y también vería de qué manera está esencialmente unida a un cuerpo como forma. ${ }^{48}$

\section{$<$ Respuesta de Olivi}

Para que, a partir de lo dicho, veas fácilmente la verdad y puedas separarla de estos errores tal como <se separa> la luz de las nubes, hay que saber que el alma se conoce o puede conocerse a sí misma de dos modos.

(i) El primer modo de conocerse a sí misma es a la manera de una sensibilidad empírica y como <si fuese > táctil (per modum sensus experimentalis et quasi tactualis). Y así el alma siente libre de toda duda que ella es, vive, piensa, quiere, ve, oye y mueve el cuerpo; $y$, además, sobre sus otros actos, sabe y siente que ella es principio y sujeto de ellos. Y esto <es así> porque el alma solo puede saber o considerar un objeto y un acto si <al mismo tiempo > sabe y siente que ella es el individuo que subyace a (suppositum) ese acto gracias al cual sabe y considera esas cosas. Por eso, además, siempre <que conoce un objeto>, $<$ simultáneamente a este conocimiento $>$ se forma en su pensamiento el convencimiento de la siguiente proposición: "yo sé esto", "yo opino esto", o bien, "yo dudo sobre esto". En efecto, el alma obtiene este conocimiento de sí misma mediante un volverse inmediato de su aspectus intelectual sobre sí misma y sobre sus propios actos. Y este aspectus, siempre que <el alma> esté en lúcido uso de su libre albedrío, está siempre y continuamente vuelto sobre ella. No obstante, como no es suficientemente lúcido para ver y distinguir todas las características esenciales y propiedades del alma, aunque la mente se sienta y se palpe inmediatamente a sí misma mediante este <aspectus >, sin embargo, no sabe discernir los géneros y las diferencias de su naturaleza por respecto de los géneros y de las diferencias de las otras cosas. ${ }^{49}$ No obstante, se sabe diferente respecto de todo lo no viviente y respecto de toda naturaleza, la cual de ningún modo puede tener en sí misma los actos aprehensivos, apetitivos y motores que el alma misma se siente tener..$^{0}$

propiedades del alma intelectiva" [Unde mens nostra non potest se intelligere ita quod seipsam immediate apprehendat; sed ex hoc quod apprehendit alia, devenit in suam cognitionem [...] Quod patet intuendo modum quo philosophi naturam animae investigaverunt. Ex hoc enim quod anima humana universales rerum naturas cognoscit, percipit quod species qua intelligimus, est immaterialis [...] Ex hoc autem quod species intelligibilis est immaterialis, perceperunt quod intellectus est res quaedam non dependens a materia; et ex hoc ad alias proprietates cognoscendas intellectivae animae processerunt]. Resaltados propios.

47 Según Jansen, Olivi se refiere a $D A \mathrm{I}, 2-4,403 \mathrm{~b} 28$ ss.

$48 \mathrm{El}$ argumento no se encuentra en Aristóteles, aunque pudo elaborarlo Olivi teniendo en mente los primeros capítulos de $D A$ I. En pocas palabras, sostiene que Aristóteles o los aristotélicos se vieron obligados a aceptar la mediación de phantasmata en el conocimiento de sí porque no encontraron otra manera de explicar las numerosas y erróneas definiciones de alma expuestas al comienzo del $D A$.

49 Sobre la noción de aspectus y su carácter táctil véase la parte final del texto anteriormente traducido y la nota 39.

50 En términos de Juhana Toivanen, esta primera modalidad de conocimiento de sí implica "la idea de que se puede ser 
(ii) El segundo modo de conocerse a sí misma consiste en un razonar mediante el cual ella investiga los géneros y las diferencias que no llega a conocer mediante el primer modo. Este razonamiento de ninguna manera parte de especies imaginarias, salvo en el caso de que sea falso y animalizado; pero en tal caso es más una creencia imaginaria que un razonamiento intelectual. Por el contrario, <este razonar, cuando es ejercido correctamente,> comienza por todo aquello que -gracias al primer modo de saber-el alma sabe y sostiene sobre sí misma a título de principio primero, infalible e indubitable; por ejemplo, que es una cosa viviente, que es principio y sujeto de todos los actos predichos. Y a partir de esto, si es perspicaz, mediante argumentación llega a la conclusión de que trasciende todo lo corpóreo. No obstante, como para argumentar esto correcta y perspicazmente es preciso que conozca la naturaleza defectuosa de los cuerpos y de lo corporal como así también la sublime naturaleza de los predichos actos del alma, y además, <es preciso que ella sea capaz de> comparar las sublimes perfecciones de los actos predichos con la naturaleza limitada de lo corporal; por todo esto es preciso que el alma haya investigado antes la naturaleza tanto de los cuerpos como de los predichos actos. Y como para conocer las naturalezas de los cuerpos nos son necesarios tanto los actos de los sentidos externos como las imágenes <que provienen de estos> a título de mensajeros que le anuncian y le presentan las cosas exteriores al intelecto; por todo esto, son necesarios los sentidos y la imaginación para este segundo modo de conocer qué es el alma.

Mediante el primer modo sé de mi alma que existe y que es principio y sujeto de los predichos actos. En cambio, sobre las almas de los otros hombres, sé esto en parte coligiéndolo a través de los sentidos, y en parte a través de una inspiración interna de mi mente. En efecto, advierto por los sentidos que en los cuerpos de los demás existen operaciones vitales, movimientos y sentidos; y a partir de esto mi mente, mediante una fuerte inspiración, estima y como que siente que los otros hombres tienen una mente semejante a ella.

\section{<Solución de las objeciones>}

El primer argumento de Aristóteles, tomado a partir del impedimento del libre uso de la razón y de la voluntad en niños, dementes y durmientes, queda refutado con lo dicho en la cuestión sobre el impedimento del uso del libre albedrío, y también con lo dicho en las anteriores tres cuestiones sobre el aspectus de las potencias cognitivas. ${ }^{51}$

El segundo argumento de los aristotélicos, tomado de los errores humanos acerca de la quididad del alma, solo concierne al segundo modo de saber. En cuanto a este $<$ modo $>$, quienes se rigen por los sentidos y van tras sus imaginaciones fácilmente se equivocan, pero no porque el conocimiento del alma se capte mediante abstracción de las especies a partir de las representaciones imaginativas sino más bien por la causa que expliqué antes.

\section{<Addendum I: sobre lo necesario para el primer modo de conocimiento de sí. Autoridades $>$}

En el primer modo de saber se exigen tres <elementos>. Lo primero es la presencia del objeto, que es la misma mente. Lo segundo es el aspectus de su intelecto vuelto o

consciente del alma sin tener conocimiento conceptual de la esencia del alma" (2013: 377).

51 Olivi se refiere a las cuestiones 73,74 y 75 , las cuales tratan, respectivamente, sobre la posibilidad de que una potencia cognitiva sea transformada desde fuera, sobre los principios internos del conocimiento, y sobre si la esencia divina puede hacer las veces de especie para el intelecto de los bienaventurados. Véase Quaest. in II Sent., v. 3: 52-144. 
convertido sobre sí mismo..$^{52}$ Lo tercero es el acto mismo de saber, que según Agustín es la imagen de la mente. Dice en De trinitate IX, capítulo 12: "Obviamente debemos sostener que tan pronto como conocemos algo, esto genera en nosotros una notitia de sí; pero esta notitia es parida por ambos, es decir, por quien conoce y por lo conocido. Por tanto, cuando la mente se conoce a sí misma, es la única progenitora de su notitia, porque ella misma es lo conocido y quien conoce. Cuando ella se conoce a sí misma, engendra su propia notitia, la cual es igual a ella, porque además de conocerse a sí misma, ella es su propia notitia; ella misma conoce y además <se conoce> a sí misma, como dijimos arriba". ${ }^{53}$ Y en el capítulo 11: "Cuando la mente se conoce a sí misma, a tal punto su notitia es su verbo que este es absolutamente igual e idéntico <a ella>; porque no es la notitia de una esencia inferior <a la mente $>-$ como <en el caso de $>$ un cuerpo- ni superior $<$ a ella $>-$ como $<$ en el caso de $>$ Dios-. Y como la notitia se asemeja a la cosa que <la mente> conoce, esto es, a aquello de lo cual <la notitia $>$ es notitia, la notitia por la cual la mente que conoce es conocida, tiene una semejanza perfecta e igual <a la mente>. Y por eso la notitia es imagen y verbo, porque expresa la mente; pues esta, conociéndo<se>, se iguala a sí misma, y lo engendrado se iguala al que engendra". ${ }^{54}$ Y Anselmo, en el Monologion, capítulo 33, dice: "Dado que la mente racional pensándose a sí misma se entiende, no hay razón para negar que nace una imagen de sí misma en su conocimiento. Y el conocimiento que ella tiene de sí es imagen suya, formada a semejanza de sí a partir de la impresión <que ella deja en sí misma>. En efecto, siempre que la mente desea pensar con verdad alguna cosa, ya sea mediante una imagen del cuerpo o mediante la razón, se esfuerza por expresar una semejanza de esta, en cuanto es capaz <de hacerlo>, en su propio acto de pensar". ${ }^{55}$ Y dice nuevamente más abajo: "Por tanto, dado que pensándose a sí misma se entiende, la mente tiene consigo su propia imagen nacida de sí misma, es decir, un conocimiento de sí misma, formado a semejanza de sí misma mediante su impresión. Y esta imagen suya es su verbo". 56

\section{<Addendum II: sobre lo necesario para el segundo modo de conocimiento de sís}

En el segundo modo de conocer se exige, como mucho, otra especie, a saber, la memorial, que retiene memorativamente la definición de alma, probada mediante las variadas conclusiones de los argumentos, y recolectada a través de las variadas divisiones de géneros y diferencias. Esta especie hace las veces de objeto inmediato, como se demostró más arriba, y no representa la quididad de la propia alma más que la de las otras <almas> de la misma especie, ya que representa la definición común de la especie completa de todas ellas. ${ }^{57}$

\section{<Precisiones finales: diversos sentidos de la expresión per essentiam>}

Cuando se pregunta si el alma se sabe por esencia, si con esto se pretende preguntar si su esencia hace las veces de especie representativa que informa la mirada (aciem) $<$ de la mente>, en ese caso la pregunta es imposible e incluso ridícula, aunque de

\footnotetext{
52 Sobre la noción de aspectus véase la nota 39.

53 Agustín, De trin. IX, 12.18; hay discrepancias entre la versión citada por Olivi y las modernas, ya sea la de Migne (PL 42) o la de Corpus Christianorum (CCSL 50A).

54 Agustín, De trin. IX, 11.16; hay discrepancias entre la versión citada por Olivi y las modernas, ya sea la de Migne (PL 42) o la de Corpus Christianorum (CCSL 50A).

55 Anselmo, Monologion XXXIII.

56 Anselmo, Monologion XXXIII.

57 En estas líneas, Olivi hace dos puntualizaciones importantes: habría algo como una quididad o esencia de lo singular, y la representación es incapaz de transmitirla; presupone, como ya hizo más arriba, que lo singular es intrínsecamente irrepresentable.
} 
hecho algunos así lo crean. Pero si con esto se entiende que su esencia es per se objeto de conocimiento, de manera que <el alma $>$ no se obyecta ante sí misma (ita quod non obiciatur sibi $)^{58}$ mediante una especie memorial, en ese caso, se afirma que en el primer modo de saber se sabe por esencia, es decir, mediante el aspectus y el acto fijado inmediatamente en su esencia. Pero si el término "mediante" (per) significa aquí la relación de causa eficiente, entonces es verdad que se conoce por la esencia de su intelecto como por medio de una causa eficiente de su acto de conocer. Y si la potencia no es capaz <de hacer> esto sin alguna luz o agudeza accidental -así como no es capaz de hacerlo sin el aspectus accidental añadido a la potencia- entonces, en ese caso, se conoce a sí misma por medio de la esencia de su potencia, pero no por medio de la esencia sola sino junto con el aspectus y el hábito sobreañadido. Aunque la notitia habitual de sí sea un accidente inseparable de ella (tal como probé en otro lugar), sin embargo, no creo que sea necesaria <esta notitia habitual> para producir el acto de conocerse, sino más bien que ese hábito es causado por la redundancia de la actualidad del intelecto en vista de saberse a sí mismo y a lo que es suyo. ${ }^{59}$

58 Para traducir obicere más dativo opto por el neologismo "obyectarse". La noética oliviana a menudo presupone en sus expresiones la unidad lingüística del sustantivo obiectum, el verbo obicere, y el participio obiectus, - $a$, -um. El predicho neologismo responde a la necesidad de que la traducción evidencie esto.

59 Olivi recapitula toda la quaestio distinguiendo los diversos sentidos de la expresión per essentiam. La expresión puede entenderse de varias maneras: (i) la esencia del alma hace las veces de especie cognoscitiva, (ii) la quididad misma (y no una especie intermedia) es objeto de scientia, (iii) la esencia del alma es causa eficiente del conocimiento que el alma misma tiene de sí, y (iv) el alma se conoce a sí misma por medio de la esencia de su potencia, a la cual se añade su aspectus. El occitano concede todos los sentidos salvo el primero, pues resulta ridícula la presuposición de que un ser pueda estar presente ante una potencia cognoscitiva y, al mismo tiempo, se represente a sí mismo. 


\section{Notas complementarias}

\section{Aristotelismo y conocimiento de sí}

Es imposible comprender estas páginas sin tener en cuenta el vehemente antiaristotelismo de Olivi. Según él, la proliferación de los escritos de Aristóteles y el interés que estos suscitaban en los maestros cristianos eran signo de una peculiar decadencia, de una suerte de "paganización" que anunciaba la inminencia del fin del mundo. A menudo -se lamenta el franciscano- Aristóteles "no prueba su opinión con ninguna razón suficiente 0 , más bien, casi con ninguna razón, pero a pesar de esto se le cree sin motivo, como a un dios de este tiempo" [nulla sufficienti ratione, immo fere nulla ratione probat suum dictum, sed absque ratione creditur sibi tanquam deo huius saeculi] (Quaest. in II Sent., v. 2: 482). Se piensa poco pero se cree demasiado: se le cree a Aristóteles incluso cuando la experiencia interior, que está al alcance de cualquiera que desee efectuarla y analizarla, diga lo contrario. El conocimiento de sí quizás constituya el caso más flagrante de esta idolatría hermenéutica.

Quizás de una manera un tanto confusa, en los textos traducidos aquí Olivi afronta dos preguntas vinculadas pero distintas (Putallaz, 1991: 90). ¿Cuál es el medio a través del cual el alma se conoce a sí misma: su propia esencia o una especie? ¿La reflexión a través de la cual el alma se conoce a sí misma es un acto autónomo o depende de otro acto previo? Aristóteles (interpreta Olivi) había respondido muy claramente ambas preguntas. En primer lugar, no hay intelección que pueda prescindir de las especies de la imaginación (phantasmata), y el conocimiento de sí no es una excepción; en segundo lugar, el conocimiento de sí nunca se da ni solo ni primero, siempre es concomitante del conocimiento de otra cosa.

Siguiendo la práctica común del discurso filosófico escolástico, en la cuestión 76 Olivi se demora en presentar los argumentos aristotélicos a favor de estas tesis. El primer argumento sostiene que el alma no puede conocerse a sí misma autónomamente y en independencia de los phantasmata porque, si esto fuese posible, toda alma -incluso la de los niños, los dementes y los durmientes- se conocería a sí misma, pero está claro que, por lo menos en estos tres casos, el alma es incapaz de conocerse a sí misma. El segundo argumento es una versión de la discordia philosophorum: el alma no puede conocerse a sí misma autónomamente y en independencia de los phantasmata porque, si esto fuese posible, toda alma -incluso la de los filósofos cuyas opiniones se exponen en De anima I- podría conocerse acertadamente a sí misma, pero está claro que, por lo menos estos filósofos se equivocaron sobre la naturaleza de su propia alma. ${ }^{60}$

Independientemente de las interpretaciones olivianas, hay en los textos de Aristóteles la idea de un conocimiento de sí o conciencia, que consiste, en términos de Rodolfo Mondolfo, en una actividad sintética de conocimiento que comienza a nivel sensible -ver y oír conllevan percibir también que se ve y se oye-y llega incluso a percibir la propia existencia (1979: 281). "Pero además -puntualiza Aristóteles- hay una potencia común que los acompaña a todos (los demás sentidos), por la cual se percibe que se ve y que se oye" [koinédýnamis akolouthousa pásais, hei kai horai kai akoúei aisthánetai] (Somn. 2, 455a15-17); ${ }^{61}$ y en otro lugar agrega: "cuando alguien se percibe a sí mismo o a otro en un tiempo continuo, no es posible que entonces se le oculte que <él mismo> existe" [me endékhetai tóte lanthánein hóti éstin] (Sens. 7, 448a26-28); y en un conocido pasaje de Metafísica, el Estagirita subraya el carácter forzosamente posterior de este autoconocimiento: "parece que la ciencia, la percepción, la opinión y el razonamiento siempre son de algo distinto <de ellos mismos> pero de sí mismos <solo > concomitantemente" [d'aeiállou [...] hautes d'en parérgoi] (Met. XII.9, 1047b35-36). A todo esto

60 Para una explicación verosímil sobre el origen de estos argumentos véase la nota 45

61 Véase además $D A$ III.2, 425b12 ss. y ENIX.9, 1170a29 ss. 
hay que agregar, las numerosas ocasiones (que Olivi tenía muy presentes) en las que advierte que es imposible inteligir algo sin imágenes (DA 431a17; Mem. 449b31, 450a13) de lo cual se infiere que una autointelección es, por principio, un acto posterior, que depende forzosamente de las imágenes proporcionadas por la sensibilidad.

Entre los contemporáneos del propio Olivi, Tomás de Aquino representa el paradigma de los cultores Aristotelis contra quienes se dirigen los dos textos traducidos aquí. Recordemos dos tesis suyas: el intelecto humano es incapaz de una intelección directa del singular y el alma humana es incapaz de conocerse a sí misma por su propia esencia.

Respecto de la primera, se lee en su Summa Theologiae que el intelecto humano es incapaz de conocer lo singular directe et primo y que solo puede hacerlo indirecte et quasi per quandam reflexionem, es decir, no primeramente sino de un modo indirecto (STh I, q. 86, a. 1, co.). Notemos que la reflexio a la que se alude aquí es un volverse del sujeto cognoscente sobre las imágenes de su propia imaginación (que a eso es a lo que se refiere Tomás con la tan mentada conversio ad phantasmata). El intelecto -explica Tomás- "Solo puede inteligir en acto según sus especies inteligibles a condición de volverse a sí mismo hacia las representaciones imaginativas" [Etiam postquam species intelligibiles abstraxit, non potest secundum eas actu intelligere nisi convertendo se ad phantasmata] (STh I, q. 86, a. 1, co.). Como se verá en la tercera nota complementaria, Olivi fue plenamente consciente de esta doctrina, y objetó que si el intelecto era incapaz de alcanzar al individuo mismo y solo podía captarlo volviéndose sobre representaciones imaginarias, peligraba seriamente la certeza del conocimiento individual. Dicho de otra manera, era imprescindible que el intelecto fuese capaz de captar directamente todos los seres individuales y, muy en especial, que fuese capaz de captarse directamente a sí mismo en su propia individualidad.

Según la segunda tesis tomasiana, el intelecto humano -si se lo considera autónomamente y por sí mismo (es decir, peressentiam) - no es un acto sino una posibilidad de actuar, es decir, un ser meramente potencial, análogo a la materia prima, que considerada en sí misma es la pura determinabilidad a nivel de los seres sensibles. "Así -sintetiza terminantemente Tomás-considerado en su esencia, [sc. el intelecto humano] de por sí solo es inteligente en potencia; por esto, por sí mismo, <solo > tiene el poder de inteligir, mientras que el poder de ser inteligido solo lo tiene a condición de que devenga en acto" [Sic igitur in sua essentia consideratus, se habet ut potentia intelligens; unde ex seipso habet virtutem ut intelligat, non autem ut intelligatur, nisi secundum id quod fit actu] (STh I, q. 87, a. 1, co). Dicho de otra manera, debido a su imperfección ontológica, el intelecto humano adolece de una suerte de intermitencia: así como la materia solo puede ser conocida por referencia a la forma, el intelecto humano -que es intelecto posible- solo puede ser conocido en la medida en que pasa al acto en virtud de alguna realidad material distinta de él. Para los seres humanos, el autoconocimiento es un acto inexorablemente segundo. En definitiva, esta doctrina de Tomás, por original que parezca, se deja leer como un desarrollo de la tesis aristotélica citada más arriba, según la cual no es posible intentar por sí mismo conocimiento de sí, puesto que es una actividad necesariamente concomitante. ${ }^{62}$

\section{Lo singular como nuevo centro noético}

Olivi desplazó el centro de la noética, y lo emplazó en lo singular. Según las tradiciones aristotélicas y platónicas, la intelección consiste, de una u otra manera, en captar lo universal; inclusive podría decirse que los seres singulares que intervienen en el proceso cognoscitivo (tanto el objeto conocido como el ser humano que lo conoce) son ocasiones o instancias para que se despliegue en ellos la intelección como proceso universal. Tanto el intelecto que conoce como la esencia conocida son poderes

62 Para la índole procesual del conocimiento de sí según Tomás de Aquino véase la nota 46. 
transindividuales que se realizan en los singulares pero los superan. En cambio, la noética oliviana reivindica el contacto inmediato con lo individual como momento fundacional del proceso cognitivo.

El estilo del discurso filosófico oliviano propende a la metáfora y a las expresiones enfáticas (abundan los adjetivos y los adverbios, a menudo en grado superlativo). A lo largo de su obra, el franciscano repite que inteligir consiste en que la atención (de un sujeto cognoscente, de este individuo específico) se fije o se clave (figere) en la cosa (es decir, en una realidad individual y concreta). No escatima palabras para subrayar esta inmediatez: praesentia, praesentialis, praesentialiter, immediate, certissime, certitudinaliter. Sin embargo, todos estos términos recalcan casi lo mismo. La característica fundamental del conocimiento no es ni su carácter abstracto, ni su universalidad, ni su inmaterialidad, sino la certeza de su contacto inmediato con lo individual.

La tradición le proporcionaba el término notitia para condensar esta novedad. Según el Oxford Latin Dictionary, las primeras acepciones del término notitia comprenden significaciones tales como "conocimiento íntimo" o "familiar", e incluso "carnal" (Glare, 1968: 1192). El término es sumamente frecuente en Agustín, que explica el conocimiento como el surgir la notitia de una res en la mente. Dentro de la escolástica, este término remite a la discusión sobre si es posible un conocimiento directo de lo individual. Respecto de esto, como dije antes, Tomás de Aquino se había pronunciado negativamente y, medio siglo más tarde, Ockham lo haría afirmativamente (suele verse en Olivi un precursor de esta tesis ockhamista) (Magnavacca, 2014: 461). Pero el término notitia en Olivi, además de ser indicio de su agustinismo, demuestra la confianza en la posibilidad de una captación inmediata de lo individual, y la voluntad de reivindicar este contacto como lo fundamental de la intelección.

Con todo, cabe preguntarse más en detalle de qué manera puede concebir la intelección -siempre necesariamente vinculada a lo universal- quien reivindica el protagonismo de lo individual. Como suele ocurrir, lo más claro de todo es la posición que Olivi pretende rechazar. Según esta, el conocimiento intelectual (es decir, intelligere, la acción de inteligir) consiste en recibir -y en hacerlo pasivamente- una especie procedente de la cosa, que representa una esencia universal, de manera tal que la intelección presupone una abstracción separativa, en virtud de la cual una representación deja aparte el ser individual y es recibida pasivamente por el intelecto que la pone delante de sí para contemplarla. Esta filosofía del conocimiento, que según Olivi es aristotélica, presenta dos problemas. Por un lado, desplaza la res individual, verdadero objeto de conocimiento, y la sustituye por una representación. Por otro lado, pasiviza al sujeto cognoscente, y degrada su actividad a mera recepción. En contra de esta posición puede leerse lo siguiente:

El intelecto solo puede inteligir algo universal sobre cosas intelectuales, si piensa al mismo tiempo en <un caso> particular, ya sea vago o definido, de ese universal. Lo cual se condice con el hecho de que lo universal ni dice ni pone nada real por fuera de sus <casos> particulares, por lo cual se lo abstrae mejor distinguiendo su ratio respecto de las rationes individuales adjuntas a él que separándolo de ellas (Quaest. in II Sent.).

Nec aliquod universale rerum intellectualium potest intelligere, nisi simul cogitet aliquod particulare vagum vel signatum illius universalis; pro eo quod universale nihil reale dicit aut ponit nisi in particularibus suis, unde potius abstrahitur distingüendo rationem eius a rationibus individualibus sibi adiunctis quam separando ipsum ab illis (Quaest. in II Sent., v. 3: 17). ${ }^{63}$

63 Para un panorama sobre el conocimiento como actividad, la causalidad cognoscitiva y el rechazo de las especies véase Suarez-Nani, 2010: 336-342. 
Es imposible captar lo universal si se deja aparte lo individual; todavía más: la captación de lo universal no es la finalidad del conocimiento sino un momento más dentro del contacto del sujeto con la cosa individual, toda vez que este contacto excede la mera abstracción separativa. La captación directa o inmediata de la realidad individual es el momento noético fundante. Pero si todo esto es así, conviene prescindir lo más posible de especies; captar lo universal no puede consistir en forjarse representaciones a fin de contemplarlas, puesto que de esa manera lo individual resultaría desplazado. La verdadera intelección consiste en un ejercicio de atención selectiva que se concentra en la realidad individual a fin de distinguir en ella las diversas rationes contenidas en esa realidad individual. ${ }^{64}$

En definitiva, la filosofía oliviana del conocimiento comienza a desarticular la tradicional división de potencias sensibles e intelectuales (aunque la siga utilizando pero superficialmente). La tradición había escindido el poder noético del sujeto cognoscente: la inmediatez y la certeza habían quedado relegadas a una forma subalterna de conocimiento, que es la sensibilidad, y a su vez la inteligencia, a pesar de su superioridad, era incapaz de captar directamente al individuo. Olivi subvierte esta distribución tradicional de funciones, y reivindica la tesis de que la inmediatez, la presencia y la certeza (características propias de la sensibilidad) son características del acto cognoscitivo como tal y, sobre todo, a nivel intelectual.

En los dos textos traducidos aquí, Olivi procura responder al problema del conocimiento de sí aplicando esta filosofía del conocimiento. Como se lee en la Cuestión 76, hay dos modos de conocimiento de sí, y el primero y más fundamental es per modum sensus experimentalis et quasi tactualis, es decir, consiste en un contacto tan inmediato y directo que se lo puede equiparar al conocimiento sensible; y su prerrogativa más importante es la indubitable certeza que proporciona acerca de que el alma existe y de que es principio y sujeto de sus propios actos. Solamente luego, en un segundo momento, de la vívida certeza de ese contacto inmediato surge un segundo modo de conocimiento, de carácter conceptual, que enfocándose en las diversas rationes del alma, discurre sobre sus géneros y sus diferencias. Sin embargo, este segundo modo de conocimiento, raciocinante y conceptual, se apoya sobre los cimientos del anterior. Según Olivi, el conocimiento de sí (igual que todo otro tipo de conocimiento) "reposa sobre el primado de la egología" (Boulnois, 1999: 174).

\section{Desconfiar de las imágenes}

La noción de imagen está en el centro mismo de los textos traducidos aquí. Olivi alude a ella utilizando el término phantasma, que remite específicamente a la imagen producida por la imaginación. No obstante, el escepticismo que se expresa en estas páginas a propósito de las imágenes de la imaginación vale para todo tipo de representación, incluidas las especies inteligibles y sensibles. El conocimiento por imágenes es lo opuesto de la captación inmediata de lo individual. Si esta última se caracteriza por su inmediatez y su certeza, las imágenes y las especies siempre son sospechosas de convertirse en velo o impedimento que distancian irreparablemente al sujeto respecto de su objeto.

La única imagen admisible es aquella que hace presente una cosa cuando esta está ausente. La única justificación de la imagen es la ausencia de la cosa, pues en cualquier

64 Acerca del universal Olivi desarrolló su teoría de las rationes, según la cual las cosas son tan completamente individuales que el universal no puede ser nada ontológicamente positivo en ellas ni una especie tomada como objeto por el intelecto sino un determinado modo de entender que el cognoscente ejerce sobre un determinado aspecto de la cosa. Dotado de esa perspicaz atención denominada aspectus, el sujeto cognoscente enfoca y compara las distintas rationes de un individuo y las descubre semejantes a las rationes de otro individuo. Olivi subraya que estas rationes, que dan pie al universal, son reales (en el sentido de que no son una mera invención del intelecto) y diversas entre ellas (en el sentido de que no son una única ratio), pero que no tienen ninguna diferencia real entre ellas (Olivi, Quaest. in II Sent., v. 1: 133 ss.: "quaeritur utrum in aliquo ente sint diversae rationes reales nullam habentes inter se differentiam realem"). Véase Martínez Ruiz, 2017: 91 ss. 
otra circunstancia la cosa se basta para representarse a sí misma. ${ }^{65}$ De aquí que la noética oliviana reduzca drásticamente las funciones de la imaginación (de hecho, defiende la tesis de que el sentido común se identifica con la imaginación) (Quaest. in II Sent., v. 2: 596 ss.). En el léxico filosófico oliviano, el sustantivo imaginatio no designa una potencia específica sino la acción (es un deverbativo) de "formar una imagen" o "figurarse algo" en la mente. Sin embargo, más importante que esta mera figuración es el acto de discernir si la imagen producida es o no una cosa de fuera, y ese acto de discernimiento le corresponde al sentido común (por eso la imaginación se identifica con él). ${ }^{66}$

La filosofía oliviana de la imagen observa dos premisas fundamentales. La imagen solo se justifica cuando subsana la ausencia de la cosa. Y quien manipula imágenes debe ejercer sobre ellas un cuidadoso discernimiento, a fin de no confundirlas con la realidad. Por eso, el tema de la imagen está íntimamente ligado al de los estados de conciencia que permiten discernir adecuadamente las imágenes. Infantes, dormientes, furiosi, es decir, niños, durmientes y locos: he aquí los estados de conciencia en los cuales es imposible discernir adecuadamente las imágenes y la mente queda expuesta a la confusión. He aquí la premisa fundamental que opera en la segunda objeción de la Cuestión 76, objeción que Olivi le imputa a Aristóteles pero que refleja mucho de su propia noética (Quaest. in II Sent., v. 2: 518 ss.).

El riesgo de que las imágenes o las especies se conviertan en un velo es una preocupación permanente.

\begin{abstract}
Cuando el aspectus de la potencia se clava inmediatísimamente en el objeto mismo, no será necesario que este último sea representado por sí mismo; por el contrario, si se interpusiese algo entre el aspectus de la potencia y el objeto mismo, más que ayudarla a ver le velaría la realidad y le impediría verla inmediatamente en sí misma (Quaest. in II Sent.).
\end{abstract}

\begin{abstract}
Quando aspectus potentiae praesentialissime figetur in ipso obiecto, non oportebit quod per aliud sibi repraesentetur quam per semetipsum; immo si aliquid interponeretur inter aspectum potentiae et ipsum obiectum, illud potius velaret rem et impediret eam praesentialiter aspici in se ipsa quam ad hoc adiuvaret (Quaest. in II Sent., v. 2: 469).
\end{abstract}

Este argumento está destinado originalmente a refutar la necesidad de las especies inteligibles. Sin embargo, como puede verse, expone razones más generales, que son las mismas que llevan -en los textos que tradujimos más arriba- a rechazar la mediación de phantasmata en el conocimiento de sí mismo. ${ }^{67}$

Como vimos, la tradición aristotélica declara que las imágenes son absolutamente imprescindibles para la intelección: "Nunca intelige el alma sin imagen" [dio oudépote noeîáneu phantásmatos he psykhé] (DA III.7, 431a16-7). Es imperioso, según Olivi, restringir el alcance de esta doctrina. Si el alma dependiese de imágenes, representaciones o especies para conocerse a sí misma, resultaría irreversiblemente vulnerado no solo el conocimiento de sí sino la certeza fundamental donde reposa todo otro conocimiento, ya que la única manera de saber con verdadera certeza que hay sol consiste en que yo conozca que conozco que hay sol. El conocimiento de sí -la certeza indiscutible de sí- es la evidencia que restringe incontestablemente la mediación de las imágenes. Por lo menos en este caso, es indiscutible la intelección directa de lo individual.

65 La especie memorial ocupa el lugar del objeto inmediato, motivo por el cual, cuando la mente recuerda un concepto, una especie memorial almacenada en la memoria intelectual deviene objeto primario de la actividad del intelecto. Según Han Adriaenssen (propenso a encontrar los problemas canónicos de la Philosophy of Mind incluso en textos premodernos) Olivi hace una concesión al realismo indirecto en este punto (2014: 80),

66 Para un estudio detallado de este punto puede consultarse Toivanen, 1997: 439-40.

67 Para una síntesis de la crítica oliviana contra las especies véase Pasnau, 1997: 168 ss.; Spruit, 1994: 215 ss. 
Pero la objeción oliviana contra las imágenes aristotélicas no se detiene aquí: el protagonismo de estas, advierte Olivi, conlleva una pasivización del intelecto. "Y sobre nuestro intelecto [Aristóteles] parece haber sostenido que [...] su acto es una mera afección (quaedam passio) efectuada por la imagen o especie imaginativa mediante la abstracción del intelecto agente" [De intellectu vero nostro videtur tenuisse quod suus actus ante acquisitionem habitus scientiae sit solum quaedam passio facta a phantasmate seu a specie imaginatlva per abstractionem intellectus agentis] (Quaest. in II Sent., v. 3: 110). El devoto fraile conoce las artes de una hermenéutica tendenciosa y transforma sutilmente la dependencia en determinismo. Hay un poder de las imágenes, cuya función no se agota en la dimensión semántica ni se limita a un puro representar. Según la lectura oliviana de la noética aristotélica, el intelecto se vería despojado de su superioridad al recibir pasivamente el influjo determinante de las imágenes iluminadas por el intelecto agente. Además de representar la cosa, las imágenes provocarían la intelección, violentarían al intelecto, lo forzarían a ejercer su acto. Ya no se trata de que el intelecto humano, a causa de su condición, dependa de las imágenes, sino del riesgo de que las imágenes acaparen la causación del conocimiento intelectual. Anotemos, de paso, que una de las preocupaciones fundamentales de las premodernas noéticas del Medioevo tardío es cómo atribuirle la intelección al cognoscente en tanto sujeto individual, punto al que le dedicaré la última nota complementaria de este trabajo.

Y hay, todavía, un último paso de la crítica oliviana de las imágenes, que consiste en la preservación del libre albedrío. Según el franciscano, el aristotelismo prescribe la siguiente serie: la cosa produce imágenes, estas afectan al intelecto y este determina el libre albedrío; se trata de una secuencia de causaciones que conlleva, a su vez, otras tantas determinaciones. Por tanto, las imágenes no solo ponen en riesgo la certeza sino también la libertad, exponen al sujeto no solo al escepticismo sino también al determinismo. En efecto, el principal locus oliviano sobre la inmediatez del conocimiento y la inutilidad de las especies es la respuesta ad 14um de la cuestión 58 de sus Quaestiones in secundum Sententiarum: mientras que el ad 14um defiende la tesis de que "las potencias cognoscitivas son totalmente activas y son causa total de sus actos", la cuestión indaga un tema netamente práctico: "Si el libre albedrío o voluntad libre es una potencia activa o pasiva" [An liberum arbitrium seu voluntas liber sit potentia activa vel passiva] (Quaest. in II Sent., v. 2: 394). La razón de esto es simple: "según mi opinión -advierte el franciscano- lo que, mucho más que otra cosa, movió a muchos [estudiosos] a creer que nuestra voluntad es totalmente pasiva fue y es que dan por cierto que todas las otras potencias son pasivas" [Quia autem illud quod meo iudicio super omnia movit multos ad credendum quod voluntas nostra sit totaliter passiva fuit et est hoc quod pro firmo tenent omnes alias potentias esse passivas] (Quaest. in II Sent., v. 2: 461).

\section{Una arqueología del sujeto moderno}

En el parágrafo 11 del Articulus 19 de la Impugnatio, el plano metafísico, el antropológico, el psicológico y el gramatical se alinean en una estructura homogénea a partir de la primacía de la experiencia subjetiva. Percipimus sensibiliter se lee en el texto, es decir, "percibimos sensiblemente", lo cual significa que con la misma certeza que los sentidos anotician la presencia de un objeto, la experiencia interior o subjetiva anoticia que detrás de cada acto humano subyace algo que es subiectum et principium de ese acto. La certeza absoluta y fundante de esta notitia comprende varios planos: a nivel metafísico muestra que cada acto humano es un accidente y que, por tanto, debe serle atribuido a una sustancia; a nivel antropológico muestra que esa sustancia a la que se atribuyen los actos es una forma, es decir, un alma; y a nivel psicológico y gramatical muestra que esa sustancia y principio activo que denominamos alma se identifica exactamente con esa experiencia psicológica que hay tras el pronombre personal "yo". 
Alain de Libera ha analizado este pasaje en varias ocasiones. En la entrada "Sujet" del Vocabulaire européen des philosophies (Cassin, de Libera, y Balibar, 2014: 1069 ss.), explica que hasta el s. XIII el medioevo dispuso de dos paradigmas antitéticos para pensar la subjetividad, uno aristotélico y otro agustiniano. Según el primero, el alma es interpretada como un subiectum cuya actividad -pensamiento, querer, etc.- corresponde al orden de lo accidental: por tanto, esta actividad no se identifica con el yo pero, al mismo tiempo, lo manifiesta (tal como ocurre con los accidentes respecto de la sustancia, que no se identifican con ella pero la dan a conocer). Según el paradigma agustiniano -originado en la teología trinitaria- es erróneo aplicarle a la Trinidad o al yo la dupla sustancia-accidente: en general, los accidentes dejan de existir y, a pesar de ello, la sustancia se mantiene (un cuerpo que cambia de color, por ejemplo); pero ni la Trinidad ni el yo pueden perder sus "manifestaciones"; Padre, Hijo y Espíritu implican la Trinidad y se implican mutuamente, y otro tanto ocurre con la memoria, el intelecto y la voluntad, respecto de la mente humana. Se trata de la doctrina trinitaria de la circumincessio o perichóresis, según la cual los elementos son inmanentes los unos a los otros, inseparables. Ahora bien, Olivi-interpreta de Libera- es uno de los primeros pensadores tardomedievales en atestiguar la síntesis de ambos paradigmas. En la Impugnatio la concepción "perichorética" agustiniana se amalgama al lenguaje peripatético de la subjetividad: si es imposible que el sujeto perciba sus propios actos sin antes percibirse a sí mismo como sujeto de ellos, es porque el "yo" es un subiectum "perichoréticamente" presente (o inmanente) en todos y cada uno de sus actos.

Años más tarde, de Libera volvió sobre el parágrafo 11 del texto oliviano y lo relacionó con Nietzsche. En el parágrafo 17 de Jenseits von Gut und Böse se deplora la idea de que el pensamiento sea un acto del yo; según Nietzsche, esta creencia no es más que una "superstición de lógicos" (Aberglauben der Logiker) y un "hábito" o "rutina gramatical" (grammatischen Gewohnheit) (1972: 40). "El hombre -así define Nietzsche esta creencia en un fragmento póstumo- se cree causa, agente; todo lo que sucede se comporta predicativamente respecto de algún sujeto" (2018: 100). Y por detrás de esta creencia, Nietzsche detecta una superstición muy antigua y constitutiva de la metafísica occidental, que consiste en hacer del pensamiento un acto del yo y, más en general, en buscarle un sujeto a cada acción. Lógicos, gramáticos y metafísicos coinciden en que a cada predicado le corresponde un sujeto agente, es decir, en que detrás de los acontecimientos debe haber algo - unas unidades duraderas últimas- que los sustenten ("la creencia en lo viviente y lo pensante como lo único que produce un efecto") (2018: 100). Independientemente de la crítica de Nietzsche (que ve en la "extraordinaria firmeza" de esta creencia el indicio de nuestra incapacidad para interpretar sucesos prescindiendo de intenciones) (2018: 100), lo que le concierne al historiador-arqueólogo de la filosofía según de Libera es explicar el origen de la red de conceptos contra la que batalla Nietzsche, es decir, descubrir cómo las nociones de "agente", "autor" y "actor" se asimilaron a (o fueron asimiladas por) la noción de "sujeto" (de Libera, 2015a). Ahora bien, es en el parágrafo 11 del artículo 19 de la Impugnatio donde de Libera encuentra el testimonio más antiguo de esta asimilación de nociones. "El sistema que critica Nietzsche -concluye taxativamente el investigador francés- fue explícita e íntegramente establecido, formulado, construido y argumentado en la Edad Media" (de Libera, 2015b: 136).

Pero nosotros solo captamos nuestros actos como predicados o atribuidos a nosotros; en efecto, cada vez que captamos nuestros actos gracias a un cierto sentido interno, además distinguimos como empíricamente entre la sustancia -de la cual <estos actos $>$ manan y en la cual existen-y los actos mismos (Olivi, Impugnatio, a. 19, \11).

Actus autem nostri non apprehenduntur a nobis nisi tamquam predicata vel nobis attributa; quando etiam nos apprehendimus nostros actus quoddam interno sensu et quasi experimentaliter distinguimus inter substantiam a qua manant et in qua existunt et inter ipsos actus (Olivi, Impugnatio, a. 19, \11. Resaltado propio). 
El alma -es decir, el yo- es capaz de percibirse inmediatamente a sí misma, y en esta autopercepción se descubre a sí misma como sujeto de sus propios actos, lo cual equivale a que percibe a estos últimos como predicados o atributos de sí misma. El principio se asimila al sujeto y el acto al predicado. Toda acción requiere un agente que sea un sujeto; toda acción requiere un sujeto que sea su agente (a esto último es a lo que Alain de Libera denomina "quiasmo de la acción", debido a la disposición quiásmica -en forma de " $\chi$ "- de las nociones de sujeto y agente).

La doctrina del parágrafo 11 -señaló finalmente de Libera- se asemeja exactamente a lo que hoy se conoce como tesis-KK ("KK-thesis"), sostenida por el filósofo finés Jaakko Hintikka en su libro Knowledge and Belief. Según la formulación lógica de esta tesis, "si $a$ conoce que $p$, entonces $a$ conoce que $a$ conoce que $p$ ", es decir, del hecho de que $a$ sepa $p$ se sigue que $a$ sabe que $a$ sabe que $p$; lo cual puede expresarse formalmente de la siguiente manera: Kap $\supset$ KaKap (donde "K" significa "knows"). Según aclaró el propio Hintikka, para que la tesis-KK sea plausible el verbo "conoce" debe ser tomado en su sentido más fuerte, es decir, no como una simple "conciencia-de" o un mero "prestaratención-a"; dicha tesis se cumple solo en el caso de que $a$ tenga razones concluyentes para sostener $p$. Hintikka indagó brevemente la presencia de su tesis en la filosofía antigua y creyó encontrarla en Platón, Aristóteles y Agustín de Hipona (Platón, Cármides, 169E ss.; Aristóteles, Met. XII.7, 1072b20 y XII.9, 1074b33 ss.; DA III.4, 429b26-430a9; EN IX.10, 1170a29-b3; y Agustín, De Trin. XV.12.21). No obstante, según se ha observado, ninguno de estos pasajes contiene la tesis de Hintikka tan nítidamente como el texto de Olivi, a quien el propio Hintikka desconocía (Hintikka, 1962: 106-110). 


\section{Bibliografía}

\section{Fuentes}

》Aristóteles (1831-1870). Aristotelis Opera. Ed. Bekker, I. 5 vols. Berolini: Preussische Akademie der Wissenschaften.

" Petrus Johannis Olivi (2010). Impugnatio. Ed. Piron, S. "Petrus Johannis Olivi. Impugnatio quorundam articulorum Arnaldi Galliardi, articulus 19". En: KönigPralong, C. et al. (eds.). Pierre de Jean Olivi - Philosophe et théologien. Actes du colloque de Philosophie médiévale. 24-25 octobre 2008. Université de Fribourg. Berlín: De Gruyter, 451-462. [También disponible en línea: Oliviana 2 (2006): journals. openedition.org/oliviana/56].

»Petrus Johannis Olivi (1922-1926). Quaestiones in secundum librum Sententiarum. Ed. Jansen, B. Quaracchi: Ex typographia Colegii Sancti Bonaventurae. (Bibliotheca Franciscana Scholastica Medii Aevi, 4 - 6).

" Petrus Johannis Olivi (1509). Impugnatio XXXV articulorum. En: Ed. Soardi, L. Quodlibeta Venecia, ff. 42r-49v.

»Thomas Aquinas (1888-1906). Summa Theologiae (Opera Omnia 4-12). Ed. Leonina: Roma.

»Thomas Aquinas (1970) Quaestiones disputatae de Veritate (Opera Omnia 22, 2/1). Ed. Leonina: Roma.

\section{Bibliografía complementaria}

"Adriaenssen, H. (2017). Representation and Scepticism from Aquinas to Descartes. Cambridge: Cambridge University Press.

»Adriaenssen, H. (2014). "Peter John Olivi and Peter Auriolon Conceptual Thought", Oxford Studies in Medieval Philosophy 2, 67-97.

"Anchepe, I. (2018). "Representaciones medievales de la visión: el caso de Pedro de Juan Olivi (†1298)", Calamus 2, 11-46. En línea: calamus.saemed.org/index. php/ calamus/article/view/35.

» Boulnois, O. (1999). Être et représentation. Une généalogie de la métaphysique moderne à l'époque de Duns Scot (XIIIe - XIVe siècle). París: Presses Universitaires de France.

» Brower-Toland, S. (2013). "Olivi on Consciousness and Self-Knowledge: The Phenomenology, Metaphysics, and Epistemology of Mind's Reflexivity", Oxford Studies in Medieval Philosophy 1, 136-171.

» Burr, D. (1976). "The Persecution of Peter Olivi", Transactions of the American Philosophical Society 66.5, 1-98.

" Burr, D. (1971). "Petrus Ioannis Olivi and the Philosophers", Franciscan Studies 31, 41-71.

»Cassin, B., de Libera, A. y Balibar, E. (2014). "Subject". En: Cassin, B. (ed.). Dictionary of Untranslatables. A Philosophical Lexicon. Princeton - Oxford: Princeton University Press. 
" De Libera, A. (2015a). "Histoire de la philosophie médiévale", L'annuaire du Collège de France 114. En línea: journals.openedition.org/annuaire-cdf/11949.

»De Libera, A. (2015b). L'invention du sujet moderne. Cours du Collège de France 2013-2014. París: Vrin.

"De Libera, A. (2014). Archéologie du sujet III. L'acte de penser 1. La double révolution. París: Vrin.

» Glare, P. (1968). Oxford Latin Dictionary. Oxford: Clarendon Press.

» Hintikka, J. (1962). Knowledge and Belief. An Introduction to the Logic of the two notions. Nueva York: Cornell University Press.

»Le Goff, J. y Truong, N. (2005). Una historia del cuerpo en la Edad Media. Buenos Aires: Paidós.

» Magnavacca, S. (2014). Léxico técnico de filosofía medieval. Buenos Aires: Miño Dávila.

» Martin, C. (2007). "Self-Knowledge and Cognitive Ascent: Thomas Aquinas and Peter Olivi on the KK-Thesis". En: Lagerlund, H. (ed.). Forming the Mind. Essays on the Internal Senses and the Mind/Body Problem from Avicenna to the Medical Enlightenment. Dordrecht: Springer.

» Martínez Ruiz, C. (2017). "Semántica e intencionalidad en Pedro de Juan Olivi. Un análisis de las fuentes de Escoto". En: Fernández, C. J. (ed.). Cuestiones de metafísica y noética en la Baja Edad Media. Córdoba: Brujas.

» Martínez Ruiz, C. (2005). Pedro de Juan Olivi. Opúsculos. Córdoba: Universidad Católica de Córdoba.

" Mondolfo, R. (1979). La comprensión del sujeto humano en la cultura antigua. Buenos Aires: Editorial Universitaria de Buenos Aires.

» Nietzsche, F. (2018). Fragmentos póstumos (1885-1889). Volumen IV. Madrid: Tecnos.

» Nietzsche, F. (1972). Más allá del bien y del mal. Madrid: Alianza.

» Pasnau, R. y Toivanen, J. (2018). "Peter John Olivi”. En: Zalta, E. (ed.). The Stanford Encyclopedia of Philosophy. Winter. En línea: plato.stanford.edu/entries/olivi/.

» Pasnau, R. (1997). Theories of Cognition in the Later Middle Ages. Cambridge: Cambridge University Press.

»Perler, D. (2003). Théories de l'intentionnalité au Moyen Âge. París: Vrin.

» Piron, S. (2007). "L'expérience subjective selon Pierre de Jean Olivi". En: Boulnois, O. Genealogies du sujet. De saint Anselme a Malebranche. París: Vrin. En línea: halshs. archives-ouvertes.fr.

» Piron, S. (2006a). "Petrus Johannis Olivi. Impugnatio quorundam articulorum Arnaldi Galliardi, articulus 19". Oliviana 2. En línea: journals.openedition.org/oliviana/52.

»Piron, S. (2006b). "Olivi et les averroïstes", Freiburger Zeitschrift für Philosophie und Theologie 53, 251-309. En línea: halshs.archives-ouvertes.fr.

»Puig Montada, J. (2005). "Averroes: Comentario mayor al libro Acerca del alma de Aristóteles. Traducción parcial", Anales del Seminario de Historia de la Filosofía 22, 65-109.

"Putallaz, F. (1991). La connaissance de soi au XIle siècle. De Matthieu d'Aquasparta a Thierry de Freiberg. París: Vrin. 
"Spruit, L. (1994). Species Intelligibilis. From Perception to Knowledge. 2 vols. Leiden: Brill.

"Suarez-Nani, T. (2010). “Notes pour l'histoire de la réception de Pierre de Jean Olivi". En: König-Pralong, C. et al. (eds.). Pierre de Jean Olivi - Philosophe et théologien. Actes du colloque de Philosophie médiévale. 24-25 octobre 2008. Université de Fribourg. Berlín: De Gruyter.

» Toivanen, J. (2013a). "Perceptual Self-Awareness in Seneca, Augustine, and Olivi", Journal of the History of Philosophy 51.3, 355-382.

" Toivanen, J. (2013b). Perception and the Internal Senses Perception. Peter of John Olivi on the Cognitive Functions. Leiden: Brill.

" Toivanen, J. (2007). "Peter Olivi on Internal Senses", British Journal for the History of Philosophy 15.3, 427-454. 